\title{
A note on the nutritional adequacy of stock diets for laboratory rats and mice
}

\author{
B. Pastuszewska ${ }^{1}$, A. Ochtabińska ${ }^{1}$ and A. Morawski ${ }^{2}$ \\ 'The Kielanowski Institute of Animal Physiology and Nutrition, \\ Polish Academy of Sciences \\ 05-110 Jablonna, Poland \\ 'Feeds and Concentrates Production Plant. A. Morawski \\ 89-240 Kcynia, Poland
}

(Received 21 December 1999; accepted 15 July 2000)

\begin{abstract}
The chemical composition of nine samples of Labofeed $\mathrm{H}$ (LH) breeding diet produced by Feeds and Concentrates Production Plant of A. Morawski (Poland) in 1997-1999 was in agreement with declared values except for a slightly lower fat content. The content of nutrients, minerals and essential amino acids conformed with the requirements of laboratory rats and mice for growth and reproduction, given by NRC (1995), except for a lower sulphur amino acids content. Composition, determined nutritional value of protein and metabolisable energy concentration, as well as the effects of feeding LH on growth performance did not differ from the values of the breeding diet produced by Altromin. The diet Labofeed B, designed for adult animals, had lower protein and metabolisable energy concentrations than $\mathrm{LH}$ and a similar nutrient profile as the respective $\mathrm{Al}$ tromin maintenance diet.
\end{abstract}

KEY WORDS: breeding diets, metabolisable energy, protein value, rats

\section{INTRODUCTION}

The composition and nutritional value of stock diets for laboratory animals have a profound influence not only on their growth, reproduction and life span but also on the response to applied experimental treatments (ICLAS, 1987). The diets commonly used in rat and mouse colonies are composed of natural ingredients and are fortified with minerals and vitamins according to requirements. It is postulated that fixed formula diets in which the kinds and amounts of ingredients do not vary 
from batch to batch be used, and that high quality raw materials from reliable sources be selected to minimize so called „within-brand" inter-batch variation (Knapka et al., 1974; ICLAS, 1987; NRC, 1995).

Laboratory rats and mice are fed ad libitum and are highly capable of adjusting their feed intake to the energy density of the diet. In the last NRC (1995) publication on nutrient requirements of laboratory animals there is no recommendation on the energy density of diets for animals in different physiological stages (maintenance vs growth and reproduction). However, according to Suzuki et al. (199la,b) there are two stages when mice, and most probably also rats, cannot maintain adequate energy intake when fed on low-cncrgy natural-ingredient diets and need a higher energy diet (ME about $3.7 \mathrm{Kcal}$ or $15.6 \mathrm{KJ} / \mathrm{g} \mathrm{DM})$. These periods are growth immediately after weaning and lactation.

On the other hand, the authors stress the importance of feeding a low-encrgy $\operatorname{diet}(2.9 \mathrm{Kcal}$ or $12.0 \mathrm{KJ} / \mathrm{g} \mathrm{DM})$ to adult non-producing animals to retard pathological changes related do aging. Such a diet is also needed when adult laboratory rats and mice are maintained in experiments of long duration.

According to these recommendations, two fixed-formula stock diets differing in energy and protein concentrations, for early post-weaning growth and reproduction, and for later stages of growth and maintenance of adult animals, were formulated and their manufacture developed in conditions guaranteeing the high quality of components and strict control of technological processes.

The objective of the study was to cvaluate the uniformity of the composition and to assess the nutritional value of the breeding dict as compared with a high quality diet produced by a foreign company and with the latest NRC dietary standards (1995). Preliminary evaluation of a maintenance diet was also performed.

\section{MATERIAL AND METHODS}

Diets

The dicts Labofeed H (LH) for breeding stock and Labofeed B (LB) for adult animals were produced by the Feeds and Concentrates Production Plant in Kcynia A. Morawski (Poland), since 1998 according to ISO 9001 Standards.

Nine samples of LH representing 400-600 kg batches purchased from regular production in the period 1997-1999 and three samples of LB produced in 1999 were analyzed for their gross chemical composition. One LH sample was analyzed for mineral and amino acid composition; in two samples the nutritional value of protein and in three, digestible and metabolisable energy value were determined. 
As a reference sample for $\mathrm{LH}$, the Altromin 1314 (A) breeding diet for rats and mice was used while chemical and amino acid composition and determined energy value of LB were compared with the declared composition and value of the Altromin maintenance 1324 diet.

\section{Determination of nutritional value}

True digestibility and biological value of protein of two samples of LH and one sample of A were determined on growing rats by the Thomas-Mitchell method according to the procedure described by Smulikowska et al. (1997). Digestible and metabolisable encrgy value of $\mathrm{LH}$ and $\mathrm{A}$ were determined on two groups of ten male rats of mean initial body weight $160 \mathrm{~g}$ (series I), that of LH and LB were measured on two groups of 16 rats of mean body weight $151 \mathrm{~g}$ (series II), and the determination of energy value of $\mathrm{LH}$ was repeated on younger rats (14 animals of body weight $112 \mathrm{~g}$, series III). The rats were housed in individual metabolic cages and total collection of faeces and urine was performed during 12 days. The excreta of two rats were pooled for analysis.

Growth performance was assayed on two groups of ten 25-day-old male rats of initial body weight $61 \mathrm{~g}$ fed for 28 days on $\mathrm{LH}$ and A diets. The animals were allocated to experimental groups according to origin (litter) and body weight and were housed in individual metabolic cages at $22-23^{\circ} \mathrm{C}$, relative humidity $50-60 \%$ and $12 \mathrm{~h} \mathrm{light/dark}$ cycle. Feed intake and body weight were controlled. At the end of the experiment the rats were killed and the weights of the pancreas, liver, kidncys and thyroid gland were registered.

The results were subjected to onc-way analysis of variance. The significance of differences was estimated by the multiple range test using Statgraphic Plus ver. 7 software.

\section{Analytical methods}

Dry matter (DM), nitrogen, ether extract (EE), ash (A) and crude fibre (CF) were analyzed using standard methods (AOAC, 1995). Amino acid analysis was performed with a Beckman 6300 High Pressure Amino Acid Analyzer using modified procedures according to Buraczewska and Buraczewski (1984). The minerals: $\mathrm{Ca}, \mathrm{K}, \mathrm{Mg}, \mathrm{Na}, \mathrm{Fc}, \mathrm{Mn}, \mathrm{Zn}, \mathrm{Cu}$ were analyzed using a Philips $\mathrm{PU}$ 9100X (Philips Scientific 1988) Atomic Absorption Spectrometer. Phosphorus was determined by AOAC procedure (1995).

Gross energy of dicts, faeces and urine was measured in a Parr adiabatic oxygen bomb calorimeter KL-10. 


\section{RESULTS AND DISCUSSION}

\section{Composition of breeding diets}

The chemical compositions of Labofeed $\mathrm{H}(\mathrm{LH})$ and Altromin 1314 (A) were very similar and consistent with declared values (Table 1) except for a lower fat content, which was also lower than the $5 \%$ recommended in Nutrient Requirements of Laboratory Animals (NRC, 1995). In spite of its relatively low total fat level, the LH diet covers the minimal requirement for linoleic acid for growth and reproduction ( 6 and $3 \mathrm{~g} / \mathrm{kg}$, respectively) according to NRC (1995) with a safety margin, since it contains about $10 \mathrm{~g}$ of linolcic acid as calculated from values given in the tables of poultry feed composition (Nutrient Requirements of Poultry, 1996).

TABLE 1

Chemical composition and mean energy value of Labofeed $\mathrm{H}$ and Altromin 1314 breeding diets as compared with declared values and recommendations of NRC (1995), \% on as fed diet

\begin{tabular}{|c|c|c|c|c|c|}
\hline \multirow[t]{2}{*}{ Item } & \multicolumn{2}{|c|}{ Labotecd $\mathrm{H}^{\prime}$} & \multicolumn{2}{|c|}{ Altromin 1314} & \multirow{2}{*}{ NRC } \\
\hline & declared & analyzed & declared & analyzed & \\
\hline Dry matter & & $88.2^{2} \pm 0.90$ & 86.5 & $90.3^{3}$ & \\
\hline Protein & 22.0 & $21.8 \pm 1.32$ & 22.5 & 21.6 & $18-25$ \\
\hline Fibre & 3.0 & $3.4 \pm 0.39$ & 4.5 & 2.6 & \\
\hline Fat & 4.4 & $3.0 \pm 0.83$ & 5.0 & 4.2 & 5 \\
\hline Ash & & $5.9 \pm 0.63$ & 6.5 & 5.3 & \\
\hline Energy value, $\mathrm{MJ} \mathrm{ME} / \mathrm{kg}$ & 13.4 & $13.9^{4}$ & 12.5 & 14.6 & 15.0 \\
\hline
\end{tabular}

1 ingredients: maize, wheat, oat flakes, green meal, soyahean oilmeal, fish meal, skim milk, soya oil, macro- and microelements, vitamins; ' mean from 9 samples \pm SD; ${ }^{3}$ one sample; 4 mean from 3 samples

The diet contains over $21 \%$ crude protein which should be considered sufficient since in practice, natural ingredient diets containing 18 to $25 \%$ crude protein support high rates of post-weaning growth and reproduction (NRC, 1995). The contents of essential amino acids, such as lysine, threoninc and tryptophan, which most often limit protein utilisation in cercal-based diets, are considerably higher in both diets (Table 2) than the levels recommended in the NRC $(1978,1995)$. The proportion of methionine in the sum of sulphur amino acids is correct but the content of methionine and cystine in both $\mathrm{LH}$ and A diets is considerably lower as compared with the very high recent NRC (1995) recommendation amounting to $9.8 \mathrm{~g}$ of total sulphur amino acids $\mathrm{kg}^{-1}$, while it greatly exceeds the requirement given in an earlier NRC (1978) edition $\left(6.0 \mathrm{~g} \mathrm{~kg}^{-1}\right)$. The authors of NRC (1995) explain the great difference between the requirement for sulphur amino acids 
TABLE 2

Content of selected essential amino acids in Labofeed $\mathrm{H}$ and Altromin 1314 breeding diets as compared with the requirement according to NRC 1978 and $1995, \mathrm{~g} / \mathrm{kg}$ of as-fed diet

\begin{tabular}{lcccc}
\hline Amino acid & Labofecd & Altromin 1314 & \multicolumn{2}{c}{ Requirement acc. to NRC } \\
\cline { 4 - 5 } & & & 1978 & 1995 \\
\hline Lysine & 13.1 & 11.9 & 7.0 & 9.2 \\
Methionine+cystine & $7.6^{1}$ & $8.0^{2}$ & 6.0 & 9.8 \\
Tryptophan & 2.8 & 2.8 & 1.5 & 2.0 \\
Threonine & 8.7 & 8.4 & 5.0 & 6.2 \\
\hline
\end{tabular}

1 methionine contributes to $56 \%$ of the sum

? methionine contributes to $52 \%$ of the sum

given in the last and previous NRC publication as a consequence of changing the statistical model used to estimate the requirement from the same experimental data. The higher values obtained using a four-parameter logistic model were included in the recent issue as more reliable. It is, however, practically impossible to obtain the recommended level of sulphur amino acids in a $20-25 \%$ protein diet composed of natural ingredients without supplementation with synthetic methionine. It seems, therefore, that the optimal level of methionine and cystine in breeding diet needs experimental verification.

The mineral composition of $\mathrm{LH}$ and A was generally consistent with declared values (Table 3) except for iron, which was 3.5 and 2.5 times greater than the respective declared levels. The possible explanation of this large discrepancy may be contamination of diets with clcmentary iron from milling and pelleting machines.

TABLE 3

Mineral composition of Labofeed $\mathrm{H}$ and Altromin 1314 breeding diets as compared with declared values and recommendations of NRC (1995), per $\mathrm{kg}$ of as fed diet

\begin{tabular}{lcccccc}
\hline Item & \multicolumn{2}{c}{ Labofeed $\mathrm{H}$} & & \multicolumn{2}{c}{ Altromin 1314} & NRC $^{1}$ \\
\cline { 2 - 3 } \cline { 5 - 6 } & declared & analyzed & & declared & analyzed & \\
\hline Calcium, g & 10.0 & 11.6 & & 9.0 & 10.9 & 6.3 \\
Phosphorus, g & 7.0 & 7.6 & & 7.0 & 7.2 & 3.7 \\
Sodium, g & 3.0 & 3.6 & & 2.0 & 2.7 & 0.5 \\
Magnesium, g & 1.5 & 2.0 & & 2.0 & 2.2 & 0.6 \\
Potassium, g & 8.0 & 8.3 & & 10.0 & 10.0 & 3.6 \\
Zinc, mg & 76.0 & 98.0 & & 60.0 & 61.0 & 25.0 \\
Copper, mg & 11.0 & 13.9 & & 13.0 & 11.3 & 8.0 \\
Iron. mg & 136 & 473 & & 160 & 405 & 75 \\
Manganese, mg & 95 & 112 & & 45 & 75 & 10 \\
\hline
\end{tabular}

1 minimal requirements for reproduction without a safety margin. Higher concentration may be warranted in natural-ingredients diets 
All analyzed macro- and trace elements were present in both dicts in amounts greater than estimates given in NRC (1995), which represent minimal concentrations without a safety margin. The greatest difference between actual and recommended values was found for manganese and may be explained by a decrease of the estimated requirement from 50 to $10 \mathrm{mg} \mathrm{kg}^{-1}$ in the last NRC (1995) publication, respectively. Given the considerably low recommended value, reduction of the dietary level in a breeding diet should be taken into consideration.

\section{Nutritional value of breeding diets}

The true digestibility (TD) and biological value (BV) of protein determined on growing rats were high and did not differ between LH and A (Table 4). Net protein utilisation (NPU), the product of TD and $\mathrm{BV}$, shows that $75 \%$ dietary protein is fully utilized when fed at a $10 \%$ level. Net protein value (NPV), which is the product of NPU and protein content in the evaluated diets, indicates that both diets contain $15-16 \%$ of physiologically available (utilizable) protein. This is more than a $12 \%$ concentration of so-called ,ideal protein" required for growth and reproduction according to $\mathrm{NRC}(1978)$ and covers the requirement for $150 \mathrm{~g}$ of highly digestible protein of balanced amino acid composition $\left(\mathrm{kg}^{-1}\right)$ according to the NRC (1995).

The results of the protein evaluation conform with data on amino acid composition and indicate that Labofeed $\mathrm{H}$ is equivalent to Altromin as a source of dietary protein.

Apparent protein digestibility determined in older rats was also similar in diets LH and A (Table 5), while digestibility of fat was higher and that of fibre lower in A than in $\mathrm{LH}$, the differences being small. Ultimately, the actual digestible (DE) and metabolisable (ME) energy concentration in both breeding diets was almost the same (Table 5) and was greater than declared values, which were 13.2 and

TABLE 4

Nutritional value of protein of Labofeed $\mathrm{H}$ and Altromin 1314 breeding diets

\begin{tabular}{lcc}
\hline Item & Labofecd $\mathbf{H}$ & Altromin 1314 \\
\hline True digestibility, TD & 86.6 & 86.3 \\
Biological value, BV & 86.6 & 84.8 \\
Net protein utilisation, NPU' & 75.0 & 73.2 \\
Net protein value, NPV' & $15.6^{3}$ & $15.8^{3}$ \\
\hline
\end{tabular}

' $\mathrm{NPU}=\frac{\mathrm{TD} \times \mathrm{BV}}{100}$

${ }^{2} \mathrm{NPV}=\mathrm{NPU} x$ crude protein content in evaluated sample of diet (3) or mean protein content in 9 samples (4) 
TABLE 5

Nutrients digestibility and energy concentration in Labofeed $\mathrm{H}$ and Altromin 1314 breeding diets

\begin{tabular}{lccccc}
\hline & \multicolumn{3}{c}{ Labofeed $\mathrm{H}$} & \multicolumn{2}{c}{ Altromin 1314} \\
\cline { 2 - 3 } Series No & J & II & III & I \\
\hline Digestibility, \% & & & & \\
$\quad$ protein & 85.7 & nd & nd & 85.3 \\
$\quad$ fat & 76.3 & nd & nd & 79.3 \\
$\quad$ fibre & 34.8 & nd & nd & 31.6 \\
N-free extractives & 92.2 & nd & nd & 91.2 \\
& & & & \\
Energy valuc, MJ/kg DM & & & & \\
$\quad$ digestible energy, DE & 16.8 & 16.2 & 16.3 & 16.9 \\
$\quad$ metabolisabic cnergy, ME & 16.1 & 15.3 & 15.4 & 16.2 \\
$\quad$ energy value, MJ ME/kg of diet as fed & 14.2 & 13.9 & 13.6 & 14.6 \\
\hline
\end{tabular}

12.5 MJ ME/kg on as-fed basis in LH and A, respectively, each value calculated in a different way (Table 1). The energy values of LH determined in series II and, especially, in series III on younger rats, were slightly lower than in series I, but not lower than declared.

The comparison of the measured and declared values is biased by the method of calculating the last data.

In contrast with domestic animals for which the systems of prediction of feed energy based on nutrient content and availability have been developed and are commonly used, there is no such system for laboratory rats and mice except for physiological fuel values (PFV), which overestimate the metabolisable energy value of natural ingredients diet by 4 to $39 \%$ (Suzuki ct al., 1990). The companies producing laboratory diets either specify energy value as gross energy (Laboratory diets reference guide, Teklad Premier), which is inappropriate, or calculate it as metabolisable energy using fixed digestibility coefficients for protein fat and $\mathrm{N}$-free extractives and energy coefficients for digestible nutrients proposed for pigs (Altromin International). The system adopted for LH and LB by the producer consists of computing the ME value of the diets using the ME of ingredients calculated according to the Müller and Kirchgessner equations for pigs (Nutrient Requirements of Pigs, 1993). The validity of such a procedure is based on the data presented by Eggum (1990) and the results of Smith ct al. (1987) and Pastuszews$\mathrm{ka}$ and Wyłuda (1992), who found that the digestible and metabolisable energy values measured in rats and pigs are very similar.

The energy concentration in both breeding diets is very close to the measured energy concentration $15.6 \mathrm{MJ} \mathrm{ME} / \mathrm{kg} \mathrm{DM}(3.73 \mathrm{Mcal} / \mathrm{kg} \mathrm{DM})$ found to be satisfactory for maximal growth and lactation of micc by Suzuki et al. (1991a). 
It may be concluded that Labofeed $\mathrm{H}$ intended for breeding colonies has sufficiently high available protein and energy concentrations to promote satisfactory growth and reproductive performance.

The results of the growth test in which 25-day-old rats were fed for 4 weeks on $\mathrm{LH}$ and A diets (Table 6) confirm the conclusion on the comparable nutritional value of Labofeed $\mathrm{H}$ and Altromin 1314 and their adequacy in promoting early growth of rats. Neither growth performance nor organ weights differed between animals fed on the two breeding diets.

\section{Composition and energy value of the Labofeed B maintenance diet}

The Labofeed B (LB) diet was designed to contain a lower level of protein and energy than Labofeed $\mathrm{H}$ to suit the needs of non-producing adult animals. Evaluation of the composition and energy concentration indicates that the LB dict contains about $2 \mathrm{MJ}$ of metabolisable energy and $4 \%$ protein less than LH and is comparable to the Altromin 1324 maintenance diet (Table 7). The energy concentration of about $13.5 \mathrm{MJ} \mathrm{ME} / \mathrm{kg}$ DM is slightly higher than recommended by Suzuki et al. (1991b) for diets retarding obesity and preventing alopecia. The concentration of protein and essential amino acids is considerably higher than recommended by NRC (1995) strictly for maintenance. The LB diet may be considered suitable for animals during later stages of growth and for non-productive adults.

\section{CONCLUSIONS}

Preliminary evaluation of the composition of the Labofecd breeding diet indicates that it covers the requirements for macronutrients of growing and reproducing animals. The composition and nutritional value of $\mathrm{LH}$ are comparable with

TABLE 6

Growth performance and organ weights of rats fed on Labofeed $\mathrm{H}$ and Altromin 1314 breeding diets

\begin{tabular}{lccc}
\hline Item & Labofeed H & Altromin 1314 & Significance \\
\hline Initial body wcight, g & 61.5 & 61.2 & $\mathrm{NS}$ \\
Final body weight, g & 214 & 213 & $\mathrm{NS}$ \\
Feed intake, g & 447 & 440 & $\mathrm{NS}$ \\
Feed conversion ratio, g/g & 2.93 & 2.90 & $\mathrm{NS}$ \\
Pancreas, g/100 g BW & 0.44 & 0.46 & $\mathrm{NS}$ \\
Liver, g/ $100 \mathrm{~g} \mathrm{BW}$ & 4.34 & 4.74 & $\mathrm{NS}$ \\
Kidneys, g/100 g BW & 0.97 & 0.97 & $\mathrm{NS}$ \\
Thryroid, mg/100 g BW & 5.92 & 5.73 & $\mathrm{NS}$ \\
\hline
\end{tabular}


TABLE 7

Chemical composition (\%), content of selected essential amino acids (\%) and energy value (MJ/kg) of maintenance diet Labofeed B as compared with declared values of respective Altromin 1324 diet

\begin{tabular}{lcccc}
\hline & \multicolumn{2}{c}{ Labofeed B } & & Altromin 1314 \\
\cline { 2 - 3 } & declared & analysed & & declared \\
\hline Crude protein & 17.0 & $18.1^{\prime}$ & 19.0 \\
Crude fibre & 6.5 & 6.2 & 6.0 \\
Fat & 2.8 & 3.0 & 4.0 \\
Ash & 1.0 & 6.2 & 7.0 \\
Lysine & 0.65 & 0.93 & 0.90 \\
Methionine+cystine & 0.22 & 0.57 & 0.60 \\
Tryptophan & 11.6 & 0.20 & 0.20 \\
Metabolisable energy, ME & & 12.0 & 11.9 \\
\hline
\end{tabular}

' ingredients: maize, wheat, oat flakes, barley, wheat bran, soyabean oilmeal, skim milk, sugar beet pulp, green meal, yeast, macro- and microelements, vitamins

those of the breeding diet produced by Altromin, which served as a reference. The possible deficiency of methionine in relation to NRC 1995, but not to NRC 1978 recommendations, should be verified.

The Labofecd B maintenance diet contains less protein and energy and may be recommended for feeding animals during later stages of growth and for non-producing adult males and females.

\section{REFERENCES}

Altromin International. Allgemeine Informationen

AOAC, 1995. Official Methods of Analysis of the Association of Official Analytical Chemists. $16^{\text {th }}$ Edition. Washington, DC

Buraczewska L., Buraczewski S., 1984. A note on the determination of methionine and tryptophane. Proceedings of $6^{\text {th }}$ International Symposium on Amino Acids, Serock (Poland), pp. 47-50

Eggum B., 1990. Protein and energy digestibility. Proceedings of the Conference: The Rat as a Model for Man and Pig in Nutritional and Physiological Studies, Stenungsbaden, pp. 77-86

ICLAS Guidelines on the Selection and Formulation of Diets for Animals in Biomedical Rescarch, 1987. M.E. Coates (Editor)

Knapka J.J., Smith K.P., Judge R.J., 1974. Effect of open and closed formula rations on the performance of three strains of laboratory micc. Lab. Anim. Sci. 24, 480-487

Laboratory Dicts Reference Guide. Teklad Premier. A Harlan Spraque Dawley Inc. Co

Nutrient Requirements of Laboratory Animals, 1978. $3^{\text {ril }}$ Edition. National Academy of Sciences. Washington, DC

Nutrient Requirements of Laboratory Animals. National Research Council, 1995. $4^{\text {th }}$ Edition. National Academy of Sciences. Washington, DC 
Nutrient Requirements of Pigs. Nutritive Value of Feeds (in Polish), 1993. The Kielanowski Institute of Animal Physiology and Nutrition (Editor), Jabłonna (Poland)

Nutrient Requirements of Poultry. Nutritive Value of Fecds (in Polish). 1996. The Kielanowski Institute of Animal Physiology and Nutrition (Editor), Jabłonna (Poland)

Pastuszewska B., Wyłuda H., 1992/1993. Energy value of cereal grains for rats (in Polish). Zwicrz. Lab. 29/30, 95-101

Smith W.C., Moughan P.J., Pearson G., James K.A.C., 1987. Comparative bioavailable energy value of five ground cereal grains measured with growing rats and pigs. Anim. Feed Sci. Tech. 18. 143-150

Smulikowska S., Pastuszewska B., Micczkowska A., Ochtabińska A., 1997. Chemical composition, energy value for chickens, and protein utilization in rats of rapeseed expeller cakes produced by different pressing technologies. J. Anim. Feed Sci. 6, 109-121

Suzuki T., Shimizu M., Ishibashi T., 1990. Proper energy evaluation of commercial laboratory animal diets based on digestibility and metabolisable energy values. Exp. Anim. 39, 557-564

Suzuki T., Shimizu M., Ishibashi T., 1991a. Effect of the energy density of non purfied diets on growth, gestation and lactation in mice. Exp. Anim. 40, 305-314

Suzuki T., Tana-ami S., Fujiwara H., Ishibashi T., 1991b. Effect of energy density of non-purified diets on reproduction, obesity, alopecia and aging in mice. Exp. Anim. 40, 449-509

\section{STRESZCZENIE}

\section{Diety dla hodowlanych zwierząt laboratoryjnych - sklad i wartość pokarmowa}

Oznaczony skład podstawowy 9 prób paszy hodowlancj Labofeed H (LH) produkowanej przez. Wytwórnię Pasz i Koncentratów A. Morawski w Kcyni w latach 1997-1999 był zgodny ze składem deklarowanym z wyjątkiem nieco niższej zawartości tłuszczu. Zawartość składników odżywczych, związków mineralnych i niczbędnych aminokwasów była zgodna z zapotrzebowaniem hodowlanych laboratoryjnych myszy i szczurów podanymi przez NRC (1995) z wyjątkiem niższej zawartości aminokwasów siarkowych. Skład, oznaczona wartość odżywcza białka i wartość energij metabolicznej LH, a także wpływ tej paszy na wzrost i rozwój szczurów, nie różniły siç od wartości diety hodowlanej produkowanej przez firmę Altromin. Pasza Labofeed B przeznaczona dla zwierząt dorosłych miała mniejszą zawartość białka i energii niż LH i podobny skład jak dieta bytowa produkcji Altrominu. 